\title{
情報システムと 兴の材料
}

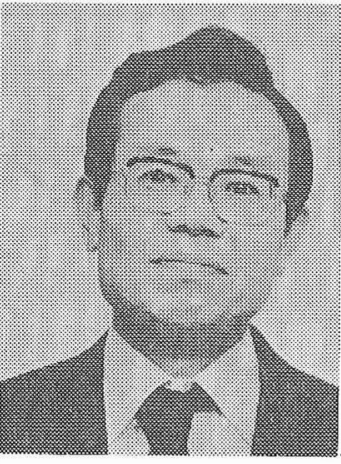

島田潤一 日本電信電話公社茨 城電気通信研究所 企画管理室 (319-11 茨城県那珂郡東海村白 方白根 162) 統括調查役

昭和 34 年大阪大学理学部化学 科卒. 同年電電公社 通 信 研入 所, 成形部研究室長, 高分子材 料研究室長を経て現在に至る. 有機高分子電子材料の研究と研 究企画に従事. <趣味>碁, ゴ ルフ, 釣り

\section{島田潤一}

Jun-ichi Shimada, 電電公社 茨城電気通信研究所

\section{1.は じめに}

人類は四つの情報革新を経験し，今第五の情報革新 の段階に入りつつあると言われている，情報システム の発展はアルピン・トフラーのいら「第三の波」の中 で中枢的役割を果たすものと考觉られる．情報革新の 段階的変遷と高分子材料の関与を第 1 表に示す. 高分 子材料に要求される特性もそれぞれの段階で大きく飛 躍し, これに応兄開発された高分子材料は広く情報シ ステムの中に取り入れられてきた．今後の情報システ 么の発展を推定し，有機高分子材料にどのような特性 が要求されるかを以下に考察してみる.

\section{2. 情報システムの将来}

第四の情報革新の時代は電話を中心とするアナログ 情報システムが主で，コンピュータなどローカルに発 展したデジタル情報システムと有機的結合がなかっ た. 第五の情報革新の時代の特徵は情報システムのデ ジタル化により，情報通信と情報処理システムが有機 的に結合し多様なサービスが出現することである。こ のため, システム的には電気通信とコンピュータのイ ンターフェースを整合し，両者を融合させたものが必 要であり, 高度情報通信システム (INS : インホメー ションネットワークシステム) として提案されてい る. INS のイメージの一例を第 1 図に示す.

このシステムの基本となる技術は LSI, 光ファイバ 一,デジタル通信網，ソフトウェア技術である。した がって, 材料的にはLSI, 光ファイバーに関する材料, 情報システムの入・出力装置, 周辺装置に関連するキ ーマテリアルの将来を読み取ることが必要である。

高分子材料もこのような今後の情報システムのキー マテリアルとして活躍するよう技術開発の進展が期待 される. 他材料に比べ, 有機・高分子系材料の特徵は 成形性にあって, 従来, 絶縁材料, 成形品として情報 システムの発展に大きく貢献してきた。この特長は今

Information System and the Related Materials
後も生かされるべきと考えられるが，さらに電気的， 光学的性質も開発し, 高分子材料の優れた成形性, 機 械的性質と組合せ，新しい適用分野を探っていくこと が今後重要と考学られる。

\section{LSI 関連材料}

IC より LSI へと集積度の上がる効果は集積度に比 例し，素子当たりのコストが低下するほか，消費電力 の低減, 信頼性の向上, プリント板などの周辺実装ュ ストの低減など大きな効果を持つ。このことは経済 性, 信頼性, 消費電力と発熱などの問題のため, 従来 不可能であった情報通信方式，装置を実用可能とする 革命的意義を持つととるに，新方式，装置の自由な発 想をもたらした效果は大きい。このよらに LSI は今 後も情報システム発展の柱となることは間違いなく， 関連材料の動向を把握する必要がある。

\section{3-1. レジスト材料}

LSI の作製工程に打いてレジスト材料は描画パター ソの精度を決定するキーマテリアルである．描画用の エネルギー線として, 紫外線, 遠紫外線, 電子線 (SOR よりのX線を含む)，イオンビームなどがある，高分 子系レジスト材料はこのようなエネルギー線による分 解または橋かけ反応を利用し，現像溶媒により現像 し，描画パターンを得ている。、レジスト材料に要求さ

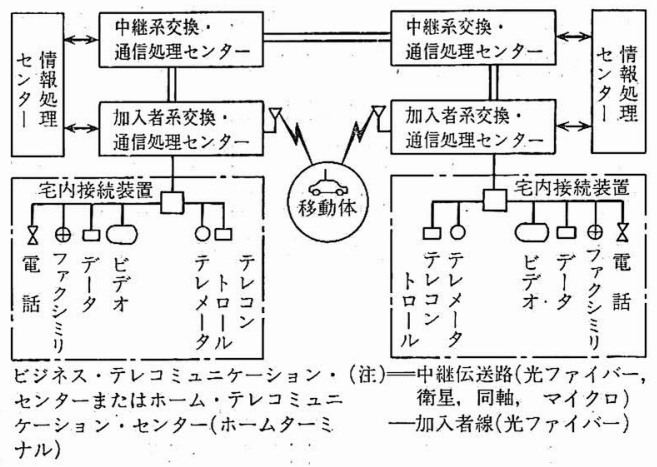

第 1 図 INS の概念図 
第 1 表 情報革新の段階的変遷と高分子材料

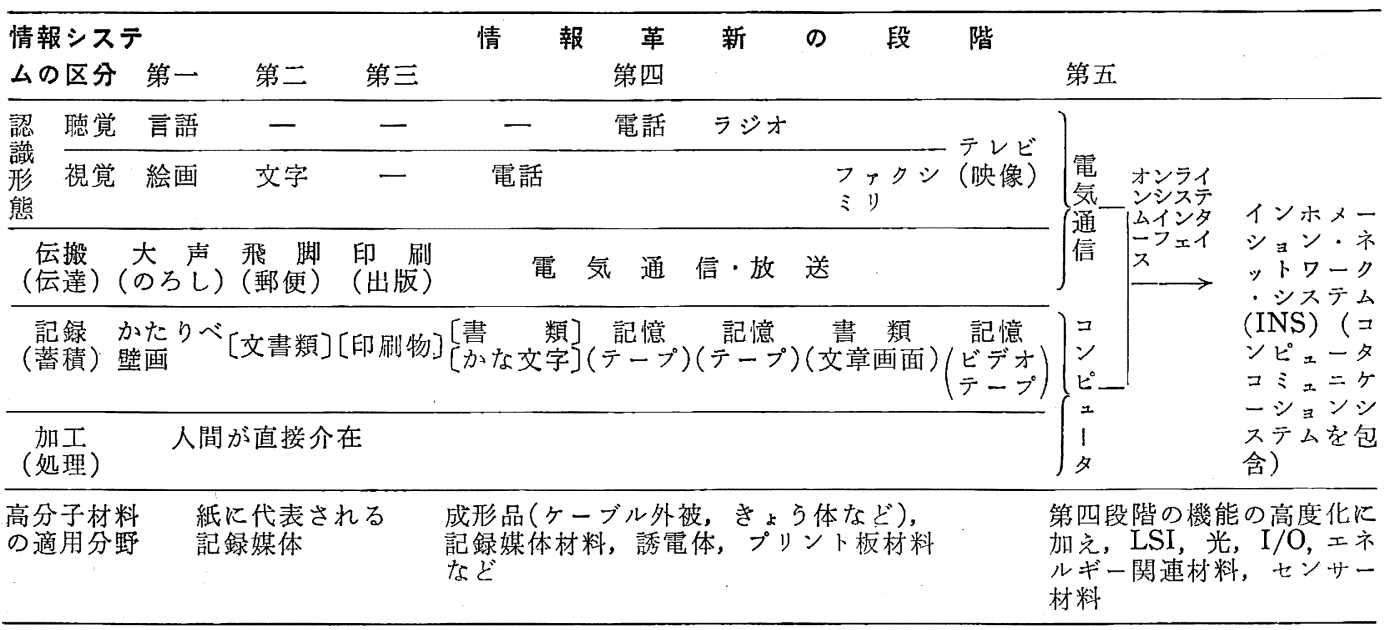

れる特性として感度, 解像度, 加工特性がある.

紫外線用レジストとしてナフトキノンジアジド系レ ジスト，環化ゴム系レジスト，ケイ皮酸ビニル系材料 が多く用いられている。解像度は光の波長より $0.5 \mu$ $\mathrm{m}$ 程度が限界と考兄られて扣り，実用的にはステップ ・アンド・リピート方式の描画機により $1.2 \sim 2.0 \mu \mathrm{m}$ 程度の解像度のものが実用され，256 Kb·MOS·RAM の製作に使われている。

電子線による描画技術は $1 \mu \mathrm{m}$ 以下の描画精度のも のと, カスタム LSI の製作を目標に開発が進められ ている.レジストとしてはポジ型では PMMA を基本 として, 感度, 解像度を改善する目的で各種の誘導体 が合成, 研究されている. ネガ型のレジストは橋かけ 形の高分子が試みられて搞り，分子量が大さいほど感 度は向上するが，解像度は低下する. 現在得られてい る代表的レジストととの特性を第 2 表に示す.

有機高分子によるレジストの解像度の限界は電子線 の光電子効果, 高分子の分子の大きさなどより $100 \AA$ 前後と考兄れる. 単純なパターンで, 基板による後 方散乱をできるだけなくして, $400 \AA^{7)}, 200 \AA^{8) な と ゙ の ~}$ データが報告されている、レジスト材料の解像度の必 要性は Si 系 LSI で $0.2 \mu \mathrm{m}$, 将来の冷凍 Si 系 LSI などで $0.02 \mu \mathrm{m}$ とされている. 極微細パターンの可 能性はそれ自体で新しい素子分野を開く刺激になる。

X線レジストは材料的に電子線レジストと同じもの が有効であり, 電子線感度とX線感度は相関のあるこ とが誌められている．X線りソグラフィの特長は基板 よりの後方散乱がないため, マスクの精度に近いパタ ーンの得られることである. SOR よりの軟X線は平 行度がよく, 線量が多く取れるため精密パターンの形 成が期待され，研究が開始されている。
第 2 表 代表的電子線レジストと特性

\begin{tabular}{|c|c|c|c|c|}
\hline タイプ & ポリマー & $\begin{array}{c}\text { 度 } \\
\left(\mathrm{cm}^{2}\right)\end{array}$ & $\gamma$ 值 & $\begin{array}{l}\text { 文献 } \\
\text { など }\end{array}$ \\
\hline \multirow{3}{*}{ 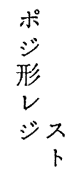 } & FBM & 0.4 & 4.5 & 1) \\
\hline & $\begin{array}{l}\text { ポリートリフルオロエチ } \\
\text { ルー } \alpha \text { ークロロアクリレート }\end{array}$ & 1 & - & 2) \\
\hline & ポリブテンスルホン & 0.7 & $(0.6)$ & 3) \\
\hline \multirow{3}{*}{$\begin{array}{l}ネ \\
\text { ガ } \\
\text { 形 } \\
\nu \\
シ \\
\pi \\
r \\
r\end{array}$} & $\begin{array}{l}\text { ポリグリシジル } \\
\text { メタクリレート }\end{array}$ & 0.1 & 2.0 & 4) \\
\hline & $\mathrm{P}(\mathrm{GMA}-\mathrm{EA})$ & 0.3 & 1.2 & 5) \\
\hline & $\begin{array}{l}\text { クロルメチル化 } \\
\text { ポリスチレン }\end{array}$ & 1.0 & 1.7 & 6) \\
\hline
\end{tabular}

イオンビームリソグラブィは電子線リソグラフィで 問題であった後方散乱による解像度の低下がなく, 近 接効果も無視できるほど小さいこと，またレジスト内 での吸収効率が高く，感度としても 2 桁近く向上する こと日)などより研究が活発化している.

遠紫外線リソグラフィは $0.5 \mu \mathrm{m}$ 程度のパターン精 度をねらったるのであり,レジストとしては電子線, X線レジストと同じ高分子レジストが有効である.

\section{3-2. プリント板}

LSI 実装用のプリント板は多層で高密度配線の可能 なもの，周辺装置用の経済的なものが求められる．計 算機の中心部の論理 LSI などは発熱量が高いため, 耐熱性と同時に放熱性の確保も問題であり, 有機高分 子系プリント板以外にセラミック多層板も用いられて いる.

耐熱性基板材料としてポリイミドが実用化されてい るが, 経済化を指向してビスマレイミド, アラルキル エーテル・フェノール系, トリアジン系などが開発さ れている。さらに熱放散，耐熱性を稀ららものとして 
第 3 表 フルアディチブ法に使う感光材料例

\begin{tabular}{|c|c|c|c|}
\hline 感光材料 & 増 感 骫 & 光源 & 光化学反応 \\
\hline $\mathrm{PdCl}_{2}{ }^{* 1}$ & $\mathrm{Fe}_{2}\left(\mathrm{C}_{2} \mathrm{O}_{4}\right)_{3}$ & UV & $\begin{array}{l}\mathrm{Fe}^{3+} \stackrel{h \nu}{\rightarrow} \mathrm{Fe}^{2+} \\
\mathrm{Fe}^{2+}+\mathrm{Pd}^{2+} \rightarrow \mathrm{Pd}^{0}\end{array}$ \\
\hline $\mathrm{PdCl}_{2} * 2$ & $\mathrm{TiO}_{2}$ & UV & $\mathrm{Pd}^{2+} \stackrel{h \nu}{\rightarrow} \mathrm{Pd}^{0}$ \\
\hline $\mathrm{H}(\mathrm{COO})_{2} \mathrm{Cu}^{* 3}$ & $\begin{array}{l}\text { アソトラキ } \\
\text { ノソジスル } \\
\text { ホソ酸 }\end{array}$ & UV & $\mathrm{Cu}^{2+} \stackrel{h \nu}{\rightarrow} \mathrm{Cu}^{0}$ \\
\hline \multirow{2}{*}{ RCOOAg*4 } & $\mathrm{ZnO}$ & UV & \multirow{2}{*}{$\mathrm{Ag}^{+} \stackrel{h \nu}{\rightarrow} \mathrm{Ag}^{0}$} \\
\hline & $\mathrm{ZnO}+$ 色素 & 可視光 & \\
\hline $\begin{array}{l}\text { *1) ウェスタン } \\
\text { *3) フォトサー }\end{array}$ & $\begin{array}{l}\text { クトリック } \\
\text { 卜社開発, }\end{array}$ & 発, & $\begin{array}{l}\text { 2) フィリップス社開発 } \\
\text { 1) 電電公社開発 }\end{array}$ \\
\hline
\end{tabular}

金属を用いた基板が研究されていて，薄膜技術を用い た MO 基板, ほう万弓引き鉄板, FOF 基板, 鉄板 コアプリント板などが開発されている.

プリント板回路形成法では高密度配線と, 経済的な 回路形成が期待できるアディチブ法の発展が期待され ている. 第 3 表に代表的なアディチブ法の感光材系を 示す.

\section{3-3. 電子デバイスの封止材料}

ハーメチックシールに代わる経済的な封止法として 樹脂封止が一般的な技術之なってきている，成形ひず みがなく，熱哊張が少なく，耐熱性，熱伝導がよい， 透水率が低く，アルカリイオンがないといらのが要求 特性であり, シリコン樹脂, エポキシ樹脂, ウレタン 樹脂などの改善したるのが用いられている.

\section{4. 光ファイバー関連材料}

光ファイバーケーブルは伝送損失が少なく、メタル ケーブルに比べ多量のデジタル情報を遠くに伝送で き，第五の情報革新での情報伝送のネックを解決する 画期的伝送媒体となるものである.

\section{4-1. 石英系光ファイバー関連材料}

光ファイバーは低損失, 広帯域, 細径, 無誘導など 優れた特徵を持っている一方，接続，側圧などによる

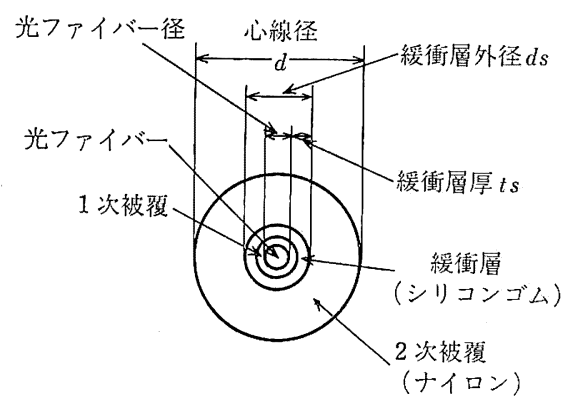

第 2 図 光ファイバー芯線の構成
損失の增加, ファイバー強度なぞの点で, 従来のメタ ルケーブルにない問題点を持っている。 このような弱 点は高分子材料により補強され，ケーブルとして実用 飞耐克るものとなっている。

光ファイバー芯線の椣造は第 2 図に示す。 ケーブル はこの芯線を集合して作られる、1次被覆は石英ファ イバー線引と同時汇行なわれ，石英ファイバーが外気 との接触によるきずの発生で, 強度が低下するのを防 ぐ役割をしている.ファイバーの線引速度は数十 $\mathrm{m} /$ 分 〜 300m/分であり， $1 \mathrm{~m}$ 足らずの硬化炉を通過する間, すなわち 1 秒足らずで被覆が完了する必要がある. 線 引速度向上のためさらに被覆速度の早いものも望まれ ている。材料的には変成シリコーン樹脂, 紫外線硬化 エポキシアリリレート樹脂, ウレタン樹脂などが用い られている．緩衝層は側圧なぞ機栈的ストレスによる ファイバーの損失增加など特性の低下を防ぐためのむ のであり, シリコーン樹脂が用いられる．2次被覆は ナイロン 12 などが用いられている.

\section{4-2. プラスチック光ファイバー}

通常のアクリル樹脂などの透明プラスチックは気 泡, ホコリなどによる散乱損失のため, $1000 \mathrm{~dB} / \mathrm{km}$ 程 度より光損失は大きく，通信用伝送媒体として使党な い.プラスチックの光損失の原因は, このような大き な製造要因による損失以外のものとして C - H の赤外 吸収の倍音, 結合音による吸収, レーリー散乱, コア とクラッドの界面の不整による損失である. プラスチ ック光ファイバーの損失限界はポリスチレンコアで $100 \mathrm{~dB} / \mathrm{km}$ くらい, PMMA で $60 \mathrm{~dB} / \mathrm{km}$, 重水素化 PMMA で 10〜20 dB/km 程度と考学られる. 第 3 図 にプラスチック光ファイバーの光損失のスペクトルを 示す, 通信用としては装置内, 架内, 架間の伝送用と して可能性があり, $100 \mathrm{~dB} / \mathrm{km}$ 以下が必要で, $20 \mathrm{~dB}$ / km 以下が望まれている.

\section{4-3. プラスチック光コネクター}

多モード形の光ファイバーの外径は $125 \pm 1 \mu \mathrm{m}$ で, コア径は $50 \pm 1 \mu \mathrm{m}$, 偏心は $\pm 1 \mu \mathrm{m}$ 程度である。

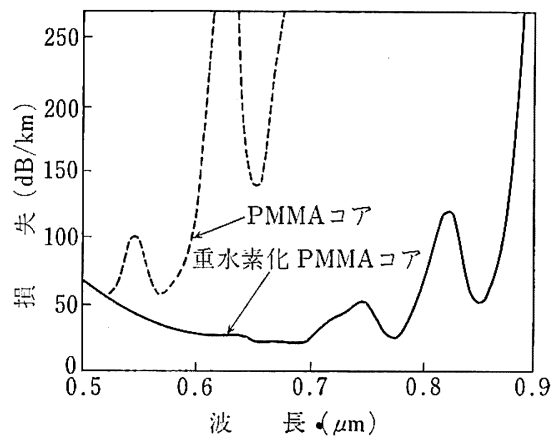

第 3 図 プラスチック光ファイバーの損失波長特性 


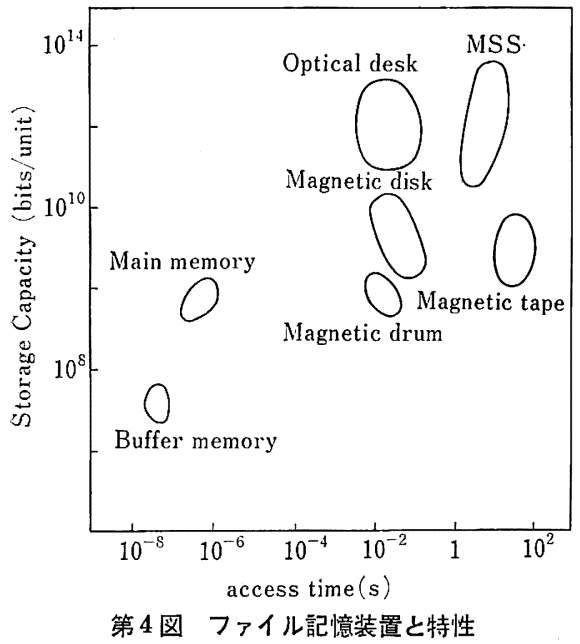

アイバー外径を合わすタイプのコネクターでは, ファ イバーかん合精度を $\pm 1 \mu \mathrm{m}$ 程度にする必要があり， プラスチック成形品で作る場合も, 同程度の成形精度 のものが必要である. 通常の精密成形品の精度は土10 〜20 $\mu \mathrm{m}$ 活どであり，不十分である. 電鋳により精密 金型を作る技術により，ファイバーを支持する部の精 度が $\pm 1 \mu \mathrm{m}$ ，偏心が $0.7 \mu \mathrm{m}$ で平均損失 $0.43 \mathrm{~dB}$ と いらプラスチックコネクターが得られている10).

\section{4-4. プラスチック光部品}

光ファイバー伝送に関連し，各部品をプラスチック化 し，経済化していく必要がある．プラスチック化の可 能性のあるものとしてつぎのようなるのがある.プラ スチックフィルム中澊波構造を作る技術を利用し， スターカップラーを作り, 挿入損失 $1.5 \mathrm{~dB}$, 信号の分 㳆屯らの $\pm 0.3 \mathrm{~dB}$ るのを得ている11)。乞の他液晶を 利用した光スイッチ・リソグラフィ技術をプラスチッ クフィルムに応用した偏光板, 分波器など有機・高分 子材料の応用分野は広く考兄られる。

\section{5. 情報入出力関連装置と材料}

情報システムの入・出力装置として各種プリンター, 表示, 入力装置があり, 重要な周辺装置としてファイ ル記録装置がある。㐌の他センサー，メカトロニクス の分野で高分子材料の活躍する場が多い。

\section{5-1. ファイル記録用材料}

実用されているファイル記録装置として磁気テー プ, ディスクが㐫り, 研究中のものとして光ディスク があり, 将来のものとしてホログラム,ケミカルホー ルバーニングなど可能性のある物理・化学現象が研究 されている，記憶容量と読出し時間により，それぞれ のファイル記憶システムの位置づけができる. 第 4 図

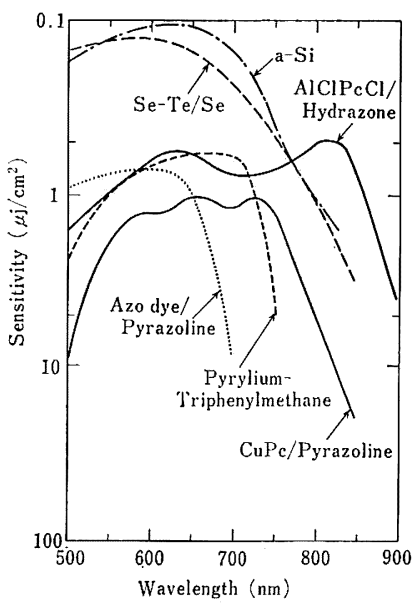

第 5 図 電子写真用感光体と特性

にその状況を示す。

磁気テープ, ディスクとる塗布形のものは $\gamma-\mathrm{Fe}_{2} \mathrm{O}_{3}$ または $\mathrm{Co}-\gamma \cdot \mathrm{Fe}_{2} \mathrm{O}_{3}$ などの磁性体を高分子バインダー に分散塗布するもので, 技術的浣成度は高いが, 今 後, 高記録密度化のため塗布厚はさらに薄く, また耐 久性も要求されるが, この問題の解決にはバインダー など高分子材料の関与するところむ大きい。

光ディスクではプラスチックディスク基板が一つの 基本技術となると考兄られる. 面精度が問題であり， 追記形などの場合, 平面度 $0.1 \mu$, 面ねじれ $100 \mu$ 程 度のものが実現している. また, 追記形以上のもので は媒体が問題であり, $\mathrm{Te}-\mathrm{CS}_{2}$ プラズマ重合膜, 金属 ポリマーなど高分子系の媒体も活躍の余地がある.

\section{5-2. 記録材料}

各方式によるプリンター, ファクシミリなど情報出 力用装置では, 記録材料は装置方式と直接関連する重 要な材料であり，高分子材料も多く使用されている.

電子写真は高速で鮮明な記録が可能である. 光源と 半導体レーザー, LED アレイなどが装置の小型化, 高速化のため使用されると考兄られ，その近赤外の発 光波長に感ずるものが必要であり, 第 5 図のような有 機・高分子系のものが研究されている.

感熱系のプリンター方式として, 感熱記録, 熱転写 記録, 通電感熱記録, 定着形感熱記録などがあり, 記 録紙には有機・高分子系の技術が多用されている。

\section{6. あとがき}

情報システムへの有機・高分子材料の応用について 述べた．この他にも，今後ニーズの大きい，軽量で容 量の大きい 2 次電池用の電極材料と電解質, センサー,

(775 頁人続く) 
$\mathrm{PA}$ 自体の電導性がそしくなり, パワー密度は低下す る. 実際, 放電に叔いて1\%以下のドープ量になると 電圧も急に低下し, パワーとして有効に使えない(. 鉛バッテリーのように過放電による電極の劣化はない が, ドープ量 $1 \%$ 以上で充放電を行ならとェネルギー 効率も高くなる。 パワー密度が大きいことは, 逆に充 電電流も大きくとれる，例党ば， PA/Li バッテリー の場合, $100 \mathrm{~A} / \mathrm{kg}$ の速さで充電可能で, 鉛バッテリ 一の 10 倍以上である。 また PA 中のドーパントの分 布はマクロな意味で均一である.

エネルギー密度, パワー密度とも， CP バッテリー が圧到的に優れているとい光よう。しかし，CP の比 重は鉛のほぼ $1 / 10$ である. 同じ容積で鉛バッテリー と比較すると, 重量は $1 / 10$, エネルギー密度( $20 \%$ ド ープできるとして） $1 / 2$ ，パワーは 3 倍といったと ころである，冒頭で述べた数值とはかなり開きがある ようだ.

実際にバッテリーを構成する場合，CP バッテリー は加工が自由にできるため, 空間を有効に使うことが でさようら゙．また㪕量であるため電極支持体，ケース などの減量化も可能である.こういった点を考慮する と, 意外に軽量, コンパクト化できるかもしれない。 $\mathrm{CP}$ バッテリーの今後の研究課題は, サイクル寿命 と安定性であ万う、残念ながら、研究が始をったばか りでこれらの十分なデータはない, しかし, 完全密封 型の PA/Li バッテリーに掠いて，2.5\%までのドープ 量であれば全く劣化なしに充放電できることが確認さ れている4)。また過充電での安定性の問題は、エネル ギー密度のアップと相まって重要である. 適当な電解 液の選択が, 解決への重要な鍵をもつものと思われる。

\section{5. おわりに}

高分子バッテリーとして現在, 最もよく研究の進ん でいるポリアセチレン拉よびポリパラフェニレンのバ ッテリーについてその特性を述べた，今では類似の導 電性高分子を電極材料として用いる研究が盛んに行な われている. いずれの高分子が優れて拈り, バッテリ 一として実用化されるかはわからないが，新しい電極 材料が現われたことは確かである。

基本的なアイデアは米国で生まれたが，今では日本 の企業の方が, PA バッテリーの研究, 開発について は進んでいるように思われる，自動車を走らす電源と なるには、をだ先のことかもしれないが、高分子バッ テリーがニニークであるため何らかの形で商品となる のは確かで，それも意外飞早いだろう。

プラスチックバッテリーが産声をあげたとき，たま たま筆者はペンシルバニア大学でこの研究にたずさわ っていた．見てきたままを何の誇張むなしに記したつ もりである.

\section{文献}

1）金藤敬一, 谷村勝己, 吉野勝美, 犬石嘉雄 : 応用 物理, 46, 299 (1977)

2) 白川英樹, 山辺時雄: 合成金属, 化学增刊 82 , 化学同人 (1980)

3) L. W. Shacklette, R. R. Chance, D. M. Ivory, G. G. Miller, R. H. Boughman: Synth. Metal, 1, 101 (1979)

4) K. Kaneto, M. Maxfield, D. P. Nairns, A. G. MacDiarmid, A.J. Heeger: J. Chem. Soc., Faraday Trans, in Press (1982)

5) 金藤敬一：科学朝日, 42 [9] (1982)
（757 頁より続く）

エレクトロクロミックなどの表示材料, 感圧ゴム, 圧 電材料など有機・高分子材料に期待されるところは大 きい.ささらに, 将来の夢である常温超伝導材料の有力 な候補として有機・高分子は期待されていて，多分野 で活躍できる夢の多い材料といえる.

\section{文献}

1) M. Kakuchi, et al.: J. Electrochem. Soc.,124, 1648 (1977)

2) T. Tada: J. Electrochem. Soc., 126, 1829(1979)

3) M. J. Bowden, et al.: J. Electrochem. Soc., 120, 1722 (1973)

4) T. Hirai, Y. Hatano, S. Nonogaki: J. Ele- ctrochem. Soc., 118, 669 (1971)

5) L. F. Thompson, et al.: Polymer Eng. \& Sci., 14, 529 (1974)

6) S. Imamura: J. Electrochem. Soc., 126, 1628 (1979)

7) R.F. Howard, et al.: Appl. Phys. Lett., 36, 592 (1980)

8) A. N. Bores, et al.: Appl. Phys. Lett., 33, 392 (1978)

9) R. L. Seliger, et al.: J. Appl. Phys., 45, 1416 (1974)

10) T. Kurokawa, T. Yoshizawa, et al.: Electronics Letters, $3 \mathrm{rd}$, Sept, 17, 667 (1981)

11) 高戸範夫, 黒川隆志, 野須 潔: 電気通信学会, OQE-74, 高分子光カップラー $(1980,9.26)$ 